\title{
Potential legacy effects of biofuel cropping systems on soil microbial communities in southern Wisconsin, USA
}

\author{
Chao Liang $^{1,2^{*}}$, Gregg R. Sanford ${ }^{1,3}$, Randall D. Jackson ${ }^{1,3}$, Teri C. Balser ${ }^{2}$ \\ ${ }^{1}$ DOE Great Lakes Bioenergy Research Center, University of Wisconsin, Madison, USA; \\ *Corresponding Author: chaoliang@,wisc.edu \\ ${ }^{2}$ Department of Soil Science, University of Wisconsin, Madison, USA; \\ ${ }^{3}$ Department of Agronomy, University of Wisconsin, Madison, USA.
}

Received 11 March 2011; revised 16 March 2011; accepted 31 March 2011.

\begin{abstract}
Soil microbial community structure is clearly linked to current plant species composition, but less is known about the legacy effects of plant species and agricultural management practices on soil microbial communities. Using microbial lipid biomarkers, we assessed patterns of community-level diversity and abundance at depths of 0 - 10 and $10-25 \mathrm{~cm}$ from three hay (alfalfa/orchardgrass) and two corn plots in southern Wisconsin. Principal components analysis of the lipid biomarkers revealed differential composition of the soil microbial communities at the two depths. Despite similar abundance of fungi, bacteria, actinomycete, protozoa, and total microbial lipids in the hay and corn at $0-10 \mathrm{~cm}$, community structure differed with a significantly higher absolute abundance of arbuscular mycorrhizal fungi and gram-negative bacteria in the hay plots. No significant microbial lipid mass differences were detected between the two management regimes at $10-25 \mathrm{~cm}$, but the proportional dominance of bacterial gram type differed with depth. These results indicate the potential for legacy effects of annual and perennial cropping systems management on microbial community composition and suggests the importance of considering past land-use when initiating long-term agroecological trials.
\end{abstract}

Keywords: Lipid Biomarker; Alfalfa; Hay; Corn; Agroecosystem

\section{INTRODUCTION}

Concern about ecological sustainability has stimulated interest in describing the structure and function of soil microbial communities, and in understanding how they are affected by past and current land use [1-3]. Soil microbial community structure can be a sensitive indicator of sustainable land use [4,5], and the variation in soil microbial communities can further have significant impacts on ecosystem processes that are central to key ecosystem services, including plant production, carbon mineralization, nutrient decomposition, and greenhouse gas fluxes $[6,7]$.

Land use management often alters plant species composition and soil properties, which exert selective pressures on soil microbial taxa via differences in the quantity and quality of organic inputs and altered microbial competition for soil nutrients $[8,9]$. These selective pressures can play a key role in shaping the in situ composition of microbial communities [2,10-12]. Recent studies have demonstrated how plant diversity can drive the composition and function of the soil microbial community and vice versa [13-15]. Alternative plant combinations may result in unique microbial populations of bacteria and fungi with differing capabilities to utilize carbon substrates and withstand stresses. In agroecosystems, this is manifested by the effect of crop rotation - increasing microbial diversity, which can also alleviate pathogen load and reduce weed and insect populations compared to continuous monocultures $[9,16]$.

Agroecosystems are increasingly scrutinized with respect to their sustainability as the global priority of development and production of alternatives to fossil fuels as energy sources grows [17]. Biofuel feedstock production in agricultural landscapes will in all likelihood alter microbial diversity and drive changes in ecosystem function through its impact on plant species choice. However, the direction and magnitude of these changes will depend on the specific biofuel production systems implemented. Alfalfa hay and corn have considerable potential for use in the production of ethanol and other industrial materials in the United States $[18,19]$. In particular, alfalfa can contribute to making the United States 
energy independent, improving the soil resource, reducing greenhouse gas emissions, and protecting groundwater quality. Consequently, the use of alfalfa for biofuel production is receiving significant attention, despite that its refining remains underdeveloped relative to traditional corn-derived biofuel. However, because of concerns over the environmental sustainability of different crops and land management it is important to have a better understanding of the potential legacy effects of alfalfa and corn on soil microbial community abundance and composition.

Using microbial lipid biomarkers, we assessed microbial communities at two soil depths under crops with contrasting histories, a 3-year alfalfa/orchardgrass hayfield and a 3-year corn monoculture, in a southern Wisconsin agroecosystem. Microbial community fingerprints, total abundance and relative abundance of specific microbial groups, were determined to examine past management and soil depth influences on soil microbiota.

\section{METHODS}

\subsection{Study Site and Soil Sampling}

We sampled bulk soils from the 15-ha Great Lakes Bioenergy Research Center (GLBRC) cropping system experiment, located at the Arlington Agricultural Research Station of the University of Wisconsin-Madison (Arlington, WI, $\left.43^{\circ} 18^{\prime} 10.86^{\prime \prime N}, 89^{\circ} 20^{\prime} 40.09^{\prime \prime} \mathrm{W}\right)$. Roughly $2 / 3$ of the 15-ha study area was maintained as a hayfield mix of alfalfa and orchardgrass (Medicago sativa L. and Dactylis glomerata L.) and 1/3 as a corn (Zea mays L) monoculture from 2005 to 2008 . Before 2005, the entire study area was part of a long-term maize-soybean annual rotation that received annual inputs of swine effluent and UW Extension-recommended rates of inorganic fertilizer. The 15-ha area contained sixty $43 \times 27-\mathrm{m}$ plots within 5 blocks meant to account for spatial variability. Within each block, one plot (experiment unit) was randomly selected for soil microbial sampling. The nearest distance between foci plots is larger than $90-\mathrm{m}$. Based on the spatial separation and random selection we assume insignificant relationship or independence between our experimental units which are replicates of our interest. Our experimental design was pseudoreplicated [20,21] because our intent here was to describe the microbial communities and explore the potential for cropping system legacy effects in an inference space limited to our study site.

The sampled soils were classified as a Plano silt loam (fine-silty, mixed, superactive, mesic Typical Argiuldolls), which formed under tallgrass prairie and characterized by high organic matter (OM), high cation exchange capacity (CEC), and exceptional agricultural productivity (Table 1). Five 37-mm diameter soil cores were collected from a grid pattern in each plot in August of 2008 to ensure a representative sample. The cores were sectioned into two depths $(0-10 \mathrm{~cm}$ and $10-25 \mathrm{~cm})$, tran- sported back to the laboratory immediately, passed through a $6.33-\mathrm{mm}$ sieve to remove visible stones and debris, freeze-dried, and subsequently homogenized for storage at $-20^{\circ} \mathrm{C}$.

\subsection{Microbial Community Composition Analysis}

We used a hybrid procedure of phospholipid fatty acid (PLFA) and fatty acid methyl ester (FAME) analysis to assay microbial community composition [22]. The procedure was based on the extraction of signature lipid biomarkers from the cell membrane of microorganisms. Lipids were extracted, purified and identified using steps from a modified lipid extraction technique first described by Bligh and Dyer [23] for lipid extraction, combined with FAME as described by Microbial ID Inc. (Hayward, CA). Briefly, approximately 3 g lyophilized soil was extracted with phosphate buffer-chloroformmethanol $(2.7 \mathrm{ml}-3.0 \mathrm{ml}-6.0 \mathrm{ml})$. We analyzed extracts with a Hewlett-Packard Agilent 6890A gas chromatograph (Agilent Tech. Co., Santa Clara, CA) equipped with a $25-\mathrm{m} \times 0.2-\mathrm{mm} \times 0.33-\mu \mathrm{m}$ Agilent Ultra-2 $(5 \%$ phenyl)-methylpolysiloxane capillary column (Hewlett Packard, Palo Alto, CA) and flame ionization detector. MIDI's EUKARY method database was used to identify fatty acids. We added 19:0 (nonadecanoic methyl ester) and 9:0 (nonanoic methyl ester) as internal standards and used them to convert fatty acid peak areas to $\mathrm{nmol} / \mathrm{g}$ soil (absolute abundance) and mol\% (proportional abundance). We quantified the abundance of different microbial groups using the abundance of signature lipids. Microbial biomass was represented by the sum of all identifiable lipids (carbon number $<20$ ).

\subsection{Lipid Nomenclature}

Fatty acids are named according to the convention $\mathrm{X}: \mathrm{Y} \omega \mathrm{Z}$, where " $\mathrm{X}$ " is the number of carbon atoms, "Y" is the number of double bonds, and " $Z$ " is the number of carbon atoms from the methyl end of the molecule to the first double bond. Branched chain fatty acids are indicated by the prefixes " $i$ " and "a" for iso and anteiso branching respectively. The prefix "cy" stands for cyclopropane ring, and "10Me" indicates methyl branching on the $10^{\text {th }}$ carbon from the carboxyl end.

\subsection{Statistical Analysis}

The mole percentage distribution of lipids was analyzed by JMP 5.0 software for principal component analysis (PCA) to identify soil microbial community 
Table 1. Selected physical and chemical characteristics of the soils from the hay and corn sites. The means and standard errors (shown in parentheses) are calculated by $t$ test $(\mathrm{P}<0.01)$ based on all plots in the field $(\mathrm{n}=36$ and 24 for hay and corn sites, respectively). Bold values indicate significant effects within depth, and underlined values indicate significant effects between sites.

\begin{tabular}{cccccccc}
\hline & $\begin{array}{c}\text { Soil Depth } \\
(\mathrm{cm})\end{array}$ & PH Value & CEC & $\begin{array}{c}\text { Total C } \\
(\%)\end{array}$ & $\begin{array}{c}\text { Total N } \\
(\%)\end{array}$ & $\begin{array}{c}\text { OM } \\
(\%)\end{array}$ & $\begin{array}{c}\text { Bulk Density } \\
\left(\mathrm{g} / \mathrm{cm}^{3}\right)\end{array}$ \\
\hline \multirow{2}{*}{ Hay } & $0-10$ & $6.49(0.03)$ & $9.70(0.27)$ & $\mathbf{2 . 1 7 ( \mathbf { 0 . 0 4 } )}$ & $\mathbf{0 . 1 8 ( \mathbf { 0 . 0 1 } )}$ & $\mathbf{3 . 7 2 ( \mathbf { 0 . 0 7 } )}$ & $\mathbf{1 . 2 9 ( \mathbf { 0 . 0 2 } )}$ \\
& $10-25$ & $6.44(0.03)$ & $9.57(0.29)$ & $\underline{\mathbf{1 . 8 3 ( 0 . 0 5 )}}$ & $\underline{\mathbf{0 . 1 5 ( 0 . 0 1 )}}$ & $\underline{\mathbf{3 . 4 7}(\mathbf{0 . 0 7})}$ & $\mathbf{1 . 5 2 ( \mathbf { 0 . 0 6 } )}$ \\
\multirow{3}{*}{ Corn } & $0-10$ & $6.55(0.06)$ & $9.44(0.46)$ & $2.22(0.07)$ & $0.22(0.02)$ & $3.75(0.08)$ & $\mathbf{1 . 2 8 ( 0 . 0 3 )}$ \\
& $10-25$ & $6.44(0.07)$ & $9.54(0.42)$ & $\underline{2.26(0.04)}$ & $\underline{0.22(0.00)}$ & $\underline{3.80(0.08)}$ & $\mathbf{1 . 3 8 ( \mathbf { 0 . 0 2 } )}$ \\
\hline
\end{tabular}

structure. Analysis of variance on the principal components (PC1 and PC2) was conducted to assess the differences in cropping system and soil depth. PCA was performed on all lipid data from the different systems and different depths. The grouping of the samples was visualized with a scatter diagram of the scores. The loading score factor for the individual lipids were used to assess the relative importance of each individual lipid in the calculation of the principal component axes. We used a general linear mixed model (GLMM) to test the effects of management regime and depth layer on soil lipid absolute and proportional abundance, including 5 subplot replicates as a random factor. GLMM was performed separately for each soil layer in order to focus on the effect of management history in this study. Sample outliers were detected by Grubbs' test $(\mathrm{P}<0.05)$. For comparisons of soil background indices at the field scale, a paired $t$ test was used to compare the means with depth, and an unpaired $t$ test to compare the means between different cropping sites $(\mathrm{P}<0.01)$.

\section{RESULTS}

Soil physical and chemical properties were generally similar between the hayfield and corn monoculture areas in $0-10 \mathrm{~cm}$ topsoil, but we did find significantly greater total carbon $(\mathrm{C})$, total nitrogen $(\mathrm{N})$ and organic matter (OM) contents in the $10-25 \mathrm{~cm}$ soil layer in the corn versus the hay site (Table 1). In the corn site by depth, we found no significant differences in $\mathrm{pH}$ value, CEC, total $\mathrm{C}$, total $\mathrm{N}$ or OM contents. The hay site, in contrast, showed a significant decrease in soil total $\mathrm{C}$, total $\mathrm{N}$ and OM contents at the $10-25 \mathrm{~cm}$ sampling depth compared to the surface layer. The bulk density at the hay site increased from $1.29 \mathrm{~g} / \mathrm{cm}^{3}$ in the $0-10 \mathrm{~cm}$ layer to 1.52 $\mathrm{g} / \mathrm{cm}^{3}$ in $10-25 \mathrm{~cm}$ layer, but did not change that significantly in the corn site (Table 1).

A total of 58 different fatty acids were identified. Of these, 43 were consistently present in the samples and used for calculating total lipid amount and PCA. These 43 fatty acids ranged in carbon chain length from $\mathrm{C} 12$ to C20. From these, 35 fatty acids known to be of microbial origin were used for determining proportional abundance and loading scores (Appendix and Table 2). The hay and corn sites contained similar total microbial lipid biomass in both $0-10 \mathrm{~cm}$ and $10-25 \mathrm{~cm}$ soil layer. The total amount of microbial lipids in $0-10 \mathrm{~cm}$ soils (mean = $201.1 \mathrm{nmol} / \mathrm{g}$ soil) was more than double (mean $=88.5$ $\mathrm{nmol} / \mathrm{g}$ soil) in the $10-25 \mathrm{~cm}$ layer.

Principal component analysis (PCA) of the lipid data suggested a substantial degree of differentiation in microbial communities between $0-10 \mathrm{~cm}$ and $10-25 \mathrm{~cm}$ (Figure 1). The first principal component axis (PC1) explained $49.9 \%$ of the variance in the data while the second principal component axis (PC2) explained 11.3\%. Overall, the differentiation of the lipid signatures between the two depths was greater than that between samples collected at the same depth from the two different cropping systems. We also note that the variance in the lipid signatures from replicate samples was higher at the $10-25 \mathrm{~cm}$ layer comparing to that from the surface $0-10 \mathrm{~cm}$ layers.

The differences in lipid signatures with soil depth primarily resulted from differences in individual lipid proportional abundances (mol\%). Individual lipids with the highest positive and the lowest negative loading scores in both sites are shown in Table 2. Indicators for protozoa and fungi had a large positive PCA loading scores on PC1 and appeared to become proportionately less abundant in $10-25 \mathrm{~cm}$ than $0-10 \mathrm{~cm}$ depth (Table 2 and Appendix). Lipids that indicate gram-positive $\left(\mathrm{Gm}^{+}\right)$bacteria and actinomycetes had large negative loading scores that appeared to increase in proportional abundance with depth (Table 2 and Appendix).

We also used specific lipids as biomarkers to quantify the abundances of specific microbial groups. For example, the lipid indicative of protozoa $(20: 4 \omega 6,9,12,15 \mathrm{c})$ was detected in the surface $0-10 \mathrm{~cm}$ soil in both cropping systems but not at the greater depth. For both cropping systems, the absolute abundance ( $\mathrm{nmol} / \mathrm{g}$ soil) of bacteria, fungi, actinomycete, protozoa and total microbial lipid biomass in $0-10 \mathrm{~cm}$ were significantly greater than at $10-25 \mathrm{~cm}$ depth. Despite similar absolute amounts of fungal, bacterial, actinomycetic, protozoal and total microbial lipids between hay and corn sites in 

A Hay $0-10 \mathrm{~cm}$
$\triangle$ Corn $0-10 \mathrm{~cm}$
- Hay $10-25 \mathrm{~cm}$
$\square$ Corn $10-25 \mathrm{~cm}$

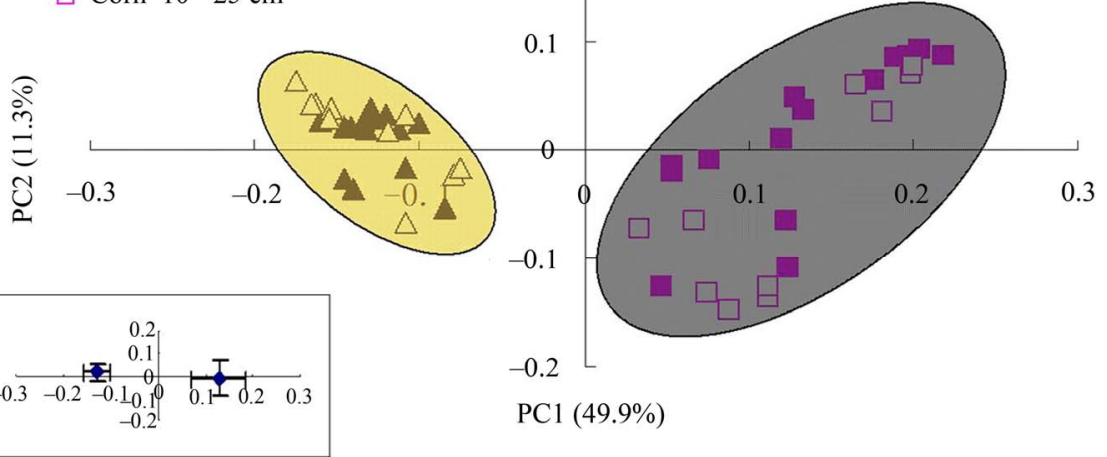

Figure 1. Principal component analysis (PCA) of lipid signatures (mol\%) from soil samples collected at two different depths within the hay and corn sites. PC1 explains $49.9 \%$ of the variance in the lipid data, PC2 explains $11.3 \%$. The PCA analysis was carried out using 43 individual lipids. Two of the 50 scores were taken away as outliers. All the $0 \sim 10$ $\mathrm{cm}$ samples were clustered in yellow shaded area, the $10-25 \mathrm{~cm}$ samples in dark shaded area. Error bars indicate standard deviations $(n=24)$.

Table 2. Individual microbial lipids most responsible for the changes in lipid signatures with depth along the first principal component (PC1). We chose the lipids with loading scores (correlations of PC1 with each lipid) that were relatively high in magnitude and had similar scores in both sites. A positive loading score is driven by a decrease in proportional abundance with depth.

\begin{tabular}{|c|c|c|c|}
\hline PLFA & $\begin{array}{l}\text { Loading score } \\
\text { in Hay site }\end{array}$ & $\begin{array}{l}\text { Loading score } \\
\text { in Corn site }\end{array}$ & $\begin{array}{l}\text { Specificity as a } \\
\text { biomarker }\end{array}$ \\
\hline $20: 4 \omega 6,9,12,15 c$ & 0.9362 & 0.9361 & Protozoa \\
\hline i14:0 & 0.9116 & 0.8059 & Gram-positive bacteria \\
\hline $17: 1 \omega 8 \mathrm{c}$ & 0.8814 & 0.9139 & Gram-negative bacteria \\
\hline $18: 2 \omega 6 \mathrm{c}$ & 0.8425 & 0.9274 & Fungi \\
\hline $15: 0$ & 0.6322 & 0.5516 & Uncertain \\
\hline $18: 1 \omega 9 \mathrm{c}$ & 0.6163 & 0.8135 & Fungi \\
\hline $18: 1 \omega 7 \mathrm{c}$ & 0.5707 & 0.7139 & Gram-negative bacteria \\
\hline 19:0cy & -0.9348 & -0.9420 & Gram-negative bacteria \\
\hline $16: 12 \mathrm{OH}$ & -0.8551 & -0.8411 & Uncertain \\
\hline i16:0 & -0.8501 & -0.6293 & Gram-positive bacteria \\
\hline a15:0 & -0.8474 & -0.7513 & Gram-positive bacteria \\
\hline $20: 0$ & -0.8455 & -0.8642 & Uncertain \\
\hline a17:0 & -0.8116 & -0.7037 & Gram-positive bacteria \\
\hline i17:0 & -0.8098 & -0.5762 & Gram-positive bacteria \\
\hline 10Me $16: 0$ & -0.7224 & -0.7834 & Actinomycete \\
\hline i15:0 & -0.6759 & -0.4260 & Gram-positive bacteria \\
\hline
\end{tabular}

the depth of $0-10 \mathrm{~cm}$ soil, microbial community structure did differ in some ways. This was most evident in the significantly higher absolute abundance of arbuscular mycorrhizal fungi (AMF) and gram-negative $\left(\mathrm{Gm}^{-}\right)$bacteria in the hay site compared to the corn (Figure 2). In addition, we found no significant system differences in microbial properties as defined by lipid biomass in the $10-25 \mathrm{~cm}$ soils. When considering the relative proportional abundances (mol\%) of specific microbial groups, we observed a significant increase in $\mathrm{Gm}^{+}$bacteria and actinomycetes with depth (Appendix). Besides the significant differences in proportional abundances (\%) of AMF between hay and corn sites in $0-10 \mathrm{~cm}$ soils as they were in the absolute abundance $(\mathrm{nmol} / \mathrm{g})$, we also found significant difference in the relative proportional abundance of $\mathrm{Gm}^{-}$bacteria in $10-25 \mathrm{~cm}$ soil between sites. Finally, the calculated lipid ratios also confirmed the community change in different microbial groups 


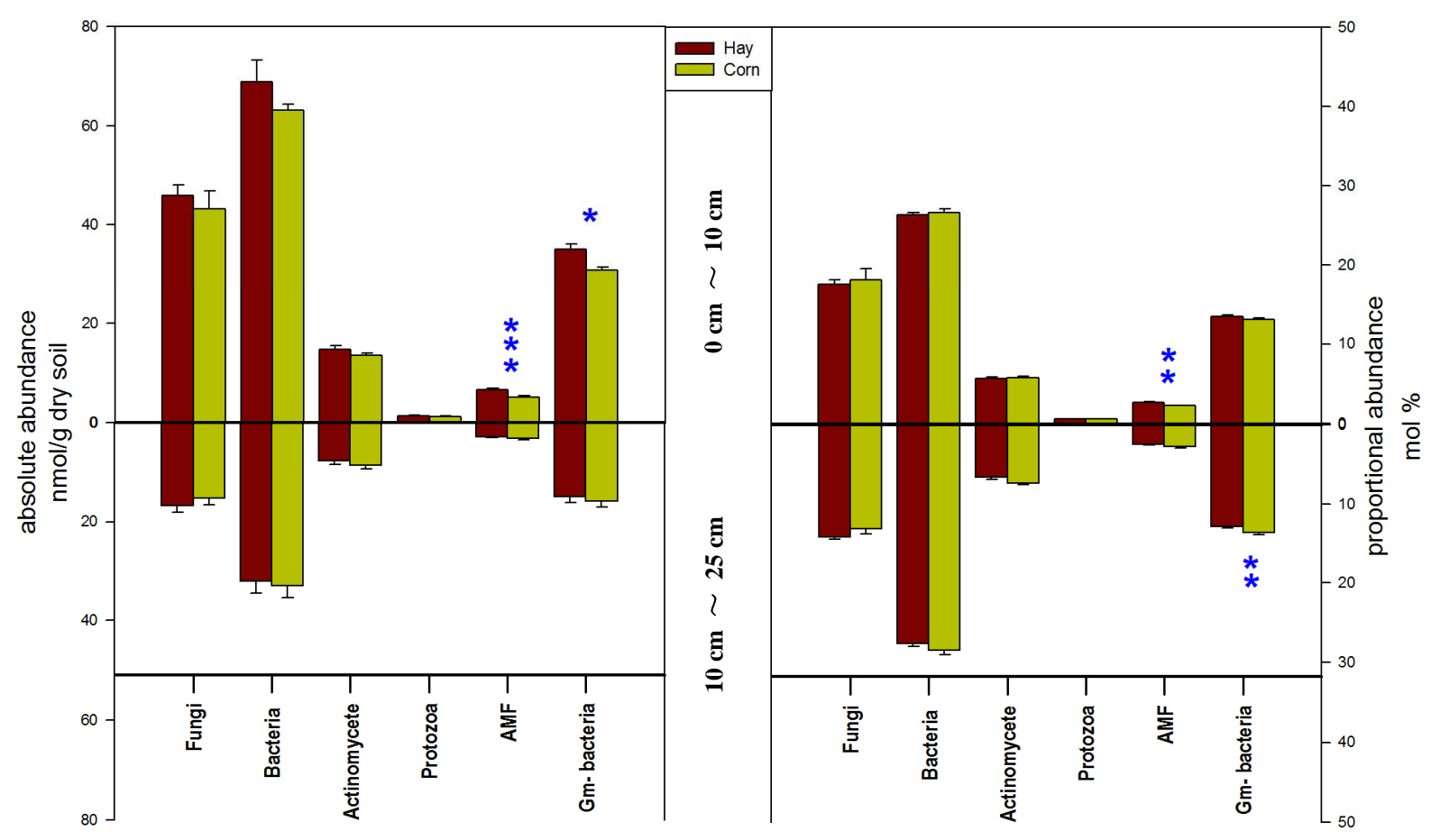

Figure 2. Changes in select microbial indices (abundance at nmol/g dry soil or mol\% by lipid) in two depths from hay and corn sites. Error bars are standard deviations. Asterisk symbol denotes a significant difference based on GLMM analysis between two sites at $* \mathrm{p}<0.1, * * \mathrm{p}<0.05, * * * \mathrm{p}<0.001$, respectively. Note: we use the sum of $16: 1 \omega 5 \mathrm{c}, 18: 1 \omega 9 \mathrm{c}, 18: 3 \omega 6 \mathrm{c}$ and $18: 2 \omega 6 \mathrm{c}$ to represent fungal lipids. $\mathrm{Gm}^{+}$bacteria are represented by the sum of i14:0, i15:0, a15:0, i16:0, i17:0 and a17:0, while the sum of

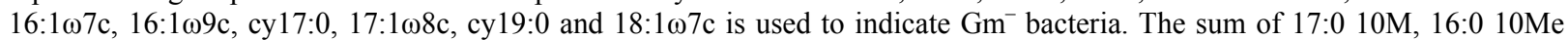
and 18:0 10Me represents actinomycete. Protozoa is represented by 20:4 6,9,12,15c, Arbuscular mycorrhizal fungi (AMF) by $16: 1 \omega 5 \mathrm{c}$ and Saprotrophic fungi (SF) by the sum of $18: 1 \omega 9 \mathrm{c}$ and 18:2 $\omega 6 \mathrm{c}$.

between two sites (data not shown). The lipid ratios of $\mathrm{Gm}^{+}$to $\mathrm{Gm}^{-}$bacteria, and saprotrohic fungi (SF) to AMF were significantly higher $(p<0.05)$ in the corn site than in the hay site in $0-10 \mathrm{~cm}$ soil layer; in the $10-25 \mathrm{~cm}$ layer, we did not detect significant difference $(\mathrm{p}>0.05)$ in lipid ratios for the fungi to bacteria, $\mathrm{Gm}^{+}$to $\mathrm{Gm}^{-}$bacteria, and SF/AMF ratios between two sites.

\section{DISCUSSION}

Aboveground crop residues function as the dominant source of nutrients for microorganisms in the upper soil horizons, while root degradants and exudates contribute organic materials at lower soil depths. At our site, the corn monoculture did not have significant chemical and physical differences between the $0-10 \mathrm{~cm}$ and $10-25$ $\mathrm{cm}$ soil layers compared with the relatively distinct layers in the alfalfa/orchardgrass hay field. We reason that this stems from the fact that corn management includes tillage while the hay systems do not. Typical tillage operations for corn disturb and partially mix the upper 20 $\mathrm{cm}$ of a soil profile. It is plausible that this mixing action resulted in the lack of difference between the $0-10 \mathrm{~cm}$ and $10-25 \mathrm{~cm}$ horizons in the corn monoculture.

In our study, soil depth appeared to have a stronger effect on soil microbial community composition than crop system underscoring the importance of biological habitat versus substrate quantity and quality on the composition of soil microorganisms. Microbial community change with depth appeared to be driven primarily by decreasing soil protozoa and fungi, and by increasing $\mathrm{Gm}^{+}$bacteria and actinomycetes in proportion to the total as indicated by the major lipid contributors. A number of other studies have also found that the soil microbial community differs with depth across varied ecosystems $[2,24,25]$. However, the greater variance in lipids we observed in the $10-25 \mathrm{~cm}$ layer compared to the surface $0-10 \mathrm{~cm}$ layer does not align with a study by Fierer et al. [25], who reported greater variance in topsoils. We suggest that the higher spatial heterogeneity in deeper layer at the corn site was caused by tillage practices mixing surface microbes into the lower soil layer; while at the hay site, heterogeneity was imparted by deeper root growth and frequent occurrence of associated $\mathrm{N}$-fixing species.

There were distinct differences in the lipid patterns between the two cropping systems. As might be expected, AMF abundance in the hay site was significantly higher than in the corn site within the $0-10 \mathrm{~cm}$ sam- 
pling depth. This was likely to the result of tillage in the corn site, which destroys fungal hyphae [26] and disrupts the signaling action initiated by rhizobial nodulation that can also stimulate mycorrhizal colonization [27]. Historic tillage may have affected $\mathrm{Gm}^{-}$bacteria as well since higher absolute abundance of $\mathrm{Gm}^{-}$bacteria and fungi were found in non-tilled than tilled $0-5 \mathrm{~cm}$ soil [28]. Higher $\mathrm{Gm}^{-}$bacterial abundance at the hay site in the $0-10 \mathrm{~cm}$ depth may be also explained by the enriched symbiotic $\mathrm{Gm}^{-} \mathrm{N}$-fixing rhizobia with legume alfalfa plants, as the rhizosphere usually harbors more $\mathrm{Gm}^{-}$bacteria and fewer $\mathrm{Gm}^{+}$bacteria [29].

In conclusion, we found that total microbial biomass was constant between hay and corn sites, but markedly decreased at the $10-25 \mathrm{~cm}$ depth in a southern Wisconsin agroecosystem. Despite similar biomass between sites, or distinct biomass between depths, there were distinct microbial communities with a greater change in composition and biomass between depths than between sites. These results suggest habitat (depth in soils) may be more important in controlling microbial community composition than plant species and that pre-existing differences in soil microbial communities under different land use legacies may serve as an important covariate in cropping systems analyses.

\section{ACKNOWLEDGEMENTS}

We would like to thank Laura Lipps, John Hall, Lawrence Oates, and Stephan Miramontes for the assistance with field sampling, Harry Read for assistance with analyzing lipid biomarkers, and Ting-Li Lin (UW-Madison Department of Statistics, CALS statistical consultant) and Masayuki Ushio for statistical expertise. This work was funded by the DOE Great Lakes Bioenergy Research Center (DOE BER Office of Science DE-FC02-07ER64494).

\section{REFERENCES}

[1] Lundquist, E.J., Scow, K.M., Jackson, L.E., Uesugi, S.L. and Johnson, C.R. (1999) Rapid response of soil microbial communities from conventional, low input, and organic farming systems to a wet/dry cycle. Soil Biology and Biochemistry, 31, 1661-1675. doi:10.1016/S0038-0717(99)00080-2

[2] Yao, H., Bowman, D. and Shi, W. (2006) Soil microbial community structure and diversity in a turfgrass chronosequence: Land-use change versus turfgrass management. Applied Soil Ecology, 34, 209-218. doi:10.1016/j.apsoil.2006.01.009

[3] Zelles, L., Rackwitz, R., Bai, Q., Beck, T. and Beese, F. (1995) Discrimination of microbial diversity by fatty acid profiles of phospholipids and lipopolysaccharides in differently cultivated soils. Plant and Soil, 170, 115-122. doi:10.1007/BF02183059

[4] Anderson, T.-H. (2003) Microbial eco-physiological indicators to asses soil quality. Agriculture, Ecosystems
\& Environment, 98, 285-293.

doi:10.1016/S0167-8809(03)00088-4

[5] Visser, S. and Parkinson, D. (1992) Soil biological criteria as indicators of soil quality: Soil microorganisms. American Journal of Alternative Agriculture, 7, 33-37. doi:10.1017/S0889189300004434

[6] Steenwerth, K.L., Jackson, L.E., Calderon, F.J., Stromberg, M.R., Scow, K.M. (2002) Soil microbial community composition and land use history in cultivated and grassland ecosystems of coastal California. Soil Biology and Biochemistry, 34, 1599-1611. doi:10.1016/S0038-0717(02)00144-X

[7] Balser, T.C. and Firestone, M.K. (2005) Linking microbial community composition and soil processes in a California annual grassland and mixed-conifer forest. Biogeochemistry, 73, 395-415. doi:10.1007/s10533-004-0372-y

[8] Nusslein, K. and Tiedje, J.M. (1999) Soil bacterial community shift correlated with change from forest to pasture vegetation in a tropical soil. Applied and Environmental Microbiology, 65, 3622-3626.

[9] Kennedy, A.C., Stubbs, T.L. and Schillinger, W.F. (2004) Soil and crop management effects on soil microbiology. CRC Press, Boca Raton, FL.

[10] Myers, R.T., Zak, D.R., White, D.C. and Peacock, A. (2001) Landscape-Level Patterns of Microbial Community Composition and Substrate Use in Upland Forest Ecosystems. Soil Science Society of America Journal, 65, 359-367. doi:10.2136/sssaj2001.652359x

[11] Grayston, S.J., Griffith, G.S., Mawdsley, J.L., Campbell, C.D. amd Bardgett, R.D. (2001) Accounting for variability in soil microbial communities of temperate upland grassland ecosystems. Soil Biology and Biochemistry, 33, 533-551. doi:10.1016/S0038-0717(00)00194-2

[12] Ushio, M., Wagai, R., Balser, T.C. and Kitayama, K. (2008) Variations in the soil microbial community composition of a tropical montane forest ecosystem: Does tree species matter? Soil Biology and Biochemistry, 40, 2699-2702. doi:10.1016/j.soilbio.2008.06.023

[13] Van der Heijden, M.G.A., Bardgett, R.D. and van Straalen, N.M. (2008) The unseen majority: soil microbes as drivers of plant diversity and productivity in terrestrial ecosystems. Ecology Letters, 11, 296-310. doi:10.1111/j.1461-0248.2007.01139.x

[14] Zak, D.R., Holmes, W.E., White, D.C., Peacock, A.D. and Tilman, D. (2003) Plant diversity, soil microbial communities, and ecosystem function: are there any links? Ecology, 84, 2042-2050. doi:10.1890/02-0433

[15] Bartelt-Ryser, J., Joshi, J., Schmid, B., Brandl, H. and Balser, T. (2005) Soil feedbacks of plant diversity on soil microbial communities and subsequent plant growth. Perspectives in Plant Ecology, Evolution and Systematics, 7, 27-49. doi:10.1016/j.ppees.2004.11.002

[16] Pankhurst, C.E., Blair, B.L., Magarey, R.C., Stirling, G.R., Garside, A.L. (2005) Effects of biocides and rotation breaks on soil organisms associated with the poor early growth of sugarcane in continuous monoculture. Plant and Soil, 268, 255-269. doi:10.1007/s11104-004-0287-3

[17] Robertson, G.P., Dale, V.H., Doering, O.C., Hamburg, S.P., Melillo, J.M., Wander, M.M., Parton, W.J., Adler, P.R., Barney, J.N., Cruse, R.M., Duke, C.S., Fearnside, 
P.M., Follett, R.F., Gibbs, H.K., Goldemberg, J., Mladenoff, D.J., Ojima, D., Palmer, M.W., Sharpley, A., Wallace, L., Weathers, K.C., Wiens, J.A. and Wilhelm, W.W. (2008) Sustainable biofuels redux. Science, 322, 49-50. doi:10.1126/science. 1161525

[18] Vadas, P., Barnett, K. and Undersander, D. (2008) Economics and energy of ethanol production from alfalfa, corn, and switchgrass in the Upper Midwest, USA. BioEnergy Research, 1, 44-55. doi:10.1007/s12155-008-9002-1

[19] Samac, D.A., Jung, H.G. and Lamb, J.F. (2006) Development of alfalfa (Medicago sativa L.) as a feedstock for production of ethanol and other bioproducts. In: Alcoholic, F. and Minteer, S. Eds., CRC Press, Boca Raton, FL, 79-98.

[20] Hurlbert, S. (1984) Psudoreplication and the design of ecological experiments. Ecological Monographs, 54, 187-211. doi: $10.2307 / 1942661$

[21] Simmons, B.L., Coleman, D.C. (2008) Microbial community response to transition from conventional to conservation tillage in cotton fields. Applied Soil Ecology, 40, 518-528. doi:10.1016/j.apsoil.2008.08.003

[22] Kao-Kniffin, J. and Balser, T.C. (2007) Elevated $\mathrm{CO}_{2}$ differentially alters belowground plant and soil microbial community structure in reed canary grass-invaded experimental wetlands. Soil Biology and Biochemistry, 39, 517-525. doi:10.1016/j.soilbio.2006.08.024

[23] Bligh, E.G. and Dyer, W.J. (1959) A rapid method of total lipid extraction and purification. Canadian Journal of Physiology, 37, 911-917. doi:10.1139/y59-099

[24] Fritze, H., Pietikainen, J. and Pennanen, T. (2000) Distribution of microbial biomass and phospholipid fatty acids in Podzol profiles under coniferous forest. European Journal of Soil Science, 51, 565-573.

[25] Fierer, N., Schimel, J.P. and Holden, P.A. (2003) Variations in microbial community composition through two soil depth profiles. Soil Biology and Biochemistry, 35, 167-176. doi:10.1016/S0038-0717(02)00251-1

[26] Jansa, J., Mozafar, A., Kuhn, G., Anken, T., Ruh, R., Sanders, I.R. and Frossard, E. (2003) Soil tillage affects the community structure of mycorrhizal fungi in maize roots. Ecological Applications, 13, 1164-1176. doi:10.1890/1051-0761(2003)13[1164:STATCS]2.0.CO; 2

[27] Xie, Z.P., Staehelin, C., Vierheilig, H., Wiemken, A., Jabbouri, S., Broughton, W.J., Vogeli-Lange, R. and Boller, T. (1995) Rhizobial nodulation factors stimulate mycorrhizal colonization of nodulating and nonnodulating soybeans. Plant Physiology, 108, 1519-1525.

[28] White, P.M., Rice, C.W. (2009) Tillage effects on microbial and carbon dynamics during plant residue decomposition. Soil Science Society of America Journal, 73, 138-145.doi:10.2136/sssaj2007.0384

[29] Paul, E.A. and Clark, F.E. (1996) Soil microbiology and biochemistry. Academic Press, San Diego.

\section{APPENDIX}

Mol\% of lipid in the different cropping sites shown as means of the measurements.

\begin{tabular}{|c|c|c|c|c|c|c|c|c|c|c|c|c|c|c|c|c|c|c|c|}
\hline \multicolumn{20}{|c|}{$\mathrm{Mol} \%$} \\
\hline $\begin{array}{l}\text { Site } \\
\text { type }\end{array}$ & $\begin{array}{c}\text { Depth } \\
\text { (cm) }\end{array}$ & $14: 0$ & i14:0 & $15: 0$ & a15:0 & i15:0 & $\begin{array}{c}15: 1 \\
\text { ISO G }\end{array}$ & $16: 0$ & $\begin{array}{l}16: 0 \\
2 \mathrm{OH}\end{array}$ & $\begin{array}{l}16: 0 \\
\text { ISO }\end{array}$ & $\begin{array}{l}16: 1 \\
2 \mathrm{OH}\end{array}$ & $\begin{array}{c}16: 1 \\
\text { ISO G }\end{array}$ & $16: 1 \omega 5 \mathrm{c}$ & $16: 1 \omega 7 \mathrm{c}$ & $16: 1 \omega 9 \mathrm{c}$ & $17: 0$ & a17:0 & cy17:0 & i17:0 \\
\hline \multirow{2}{*}{ Hay } & $0-10$ & 1.63 & 0.56 & 0.67 & 3.15 & 4.74 & 0.66 & 12.76 & 0.47 & 1.91 & 0.59 & 0.64 & 2.58 & 4.33 & 0.52 & 0.49 & 1.10 & 1.45 & 1.51 \\
\hline & $10-25$ & 1.50 & 0.10 & 0.46 & 3.93 & 5.35 & 0.26 & 11.93 & 0.00 & 2.30 & 1.05 & 0.00 & 2.45 & 3.88 & 0.27 & 0.17 & 1.31 & 0.99 & 1.85 \\
\hline \multirow{2}{*}{ Corn } & $0-10$ & 1.40 & 0.55 & 0.78 & 3.18 & 5.08 & 0.72 & 11.18 & 0.57 & 1.92 & 0.72 & 0.63 & 2.19 & 4.03 & 0.50 & 0.53 & 1.15 & 1.42 & 1.68 \\
\hline & $10-25$ & 1.46 & 0.10 & 0.56 & 3.89 & 5.35 & 0.08 & 11.70 & 0.07 & 2.17 & 1.12 & 0.00 & 2.75 & 4.13 & 0.49 & 0.37 & 1.40 & 1.53 & 1.98 \\
\hline
\end{tabular}

\begin{tabular}{|c|c|c|c|c|c|c|c|c|c|c|c|c|c|c|c|c|c|c|c|}
\hline & & & & & & & & & & $\mathrm{Mol} \%$ & & & & & & & & & \\
\hline \multirow[t]{2}{*}{$\begin{array}{l}\text { Site } \\
\text { type }\end{array}$} & $\begin{array}{l}\text { Depth } \\
(\mathrm{cm})\end{array}$ & $\begin{array}{l}17: 0 \\
\text { ISO } \\
3 \mathrm{OH}\end{array}$ & $\begin{array}{l}17: 1 \\
\omega 8 \mathrm{c}\end{array}$ & 18:0 & $\begin{array}{l}18: 0 \\
2 \mathrm{OH}\end{array}$ & $\begin{array}{l}18: 1 \\
\omega 9 \mathrm{c}\end{array}$ & $\begin{array}{c}10 \mathrm{Me} \\
17: 0\end{array}$ & $\begin{array}{l}18: 3 \\
\omega 6 \mathrm{c}\end{array}$ & 19:0 & cy19:0 & 20:0 & $\begin{array}{l}20: 1 \\
\omega 9 \mathrm{c}\end{array}$ & $\begin{array}{c}20: 4 \omega \\
691215 c\end{array}$ & $\begin{array}{c}10 \mathrm{Me} \\
16: 0\end{array}$ & $\begin{array}{l}19: 1 \\
\omega 6 \mathrm{c}\end{array}$ & $\begin{array}{l}18: 2 \\
\omega 6 \mathrm{c}\end{array}$ & $\begin{array}{c}10 \mathrm{Me} \\
18: 0\end{array}$ & $\begin{array}{l}18: 1 \\
\omega 7 \mathrm{c}\end{array}$ & Total \\
\hline & $0-10$ & 0.40 & 0.47 & 4.38 & 0.33 & 7.78 & 0.92 & 1.65 & 0.16 & 1.88 & 1.74 & 0.48 & 0.53 & 3.58 & 0.92 & 5.58 & 1.10 & 4.19 & 75.85 \\
\hline \multirow[t]{2}{*}{ Hay } & $10-25$ & 0.00 & 0.00 & 5.65 & 0.05 & 6.61 & 0.59 & 1.76 & 0.24 & 2.98 & 2.75 & 0.21 & 0.00 & 4.71 & 1.89 & 3.29 & 1.28 & 3.62 & 73.43 \\
\hline & $0-10$ & 0.47 & 0.55 & 4.04 & 0.42 & 8.89 & 0.68 & 0.93 & 0.16 & 1.91 & 1.98 & 0.52 & 0.51 & 3.81 & 1.10 & 6.15 & 1.19 & 3.92 & 75.48 \\
\hline Corn & $10-25$ & 0.00 & 0.00 & 5.31 & 0.23 & 6.32 & 0.70 & 0.98 & 0.31 & 2.86 & 2.70 & 0.00 & 0.00 & 5.24 & 1.68 & 3.10 & 1.39 & 3.49 & 73.41 \\
\hline
\end{tabular}

